\section{The Common Good and Individual Rights}

\section{Szilárd Tattay}

\section{Abstract}

Paradoxically, even though starting from a markedly individualist approach, the modern counterparts of the classical idea of public good, the Rousseauian concept of 'volonté générale' and the utilitarian notion of 'public interest' both tend to supersede and neglect the individual's will, interest and rights. To be sure, the original Aristotelian understanding of the common good also interest and rights. To be sure, the original Aristotelian understanding of the common good also
implies that in case of conflict the good of the community should take precedence over that of the individual. Nevertheless, in the classical way of thinking the public and the private good are seen as typically existing in harmony with one another rather than in a state of conflict. In this chapter I seek to elucidate the ontological presuppositions and conceptual premises underlying and the opposition of the common good to individual goods and rights.

\section{Introduction}

In this chapter I will present, albeit in a tentative and sketchy way, the essential outlines of a concept of the common good which is meaningful, coherent, viable and at the same time compatible with the idea of individual rights. In doing so I will use the more comprehensive and traditional term 'good' rather than that of 'right', and I will rely mainly on the thoughtful analysis of 'atomist' and holist ontologies offered by Charles Taylor (see esp. Taylor 1985, Taylor 1997a, Taylor 1997b), and on the now classic essay of Péter Takács (1998) on the common good.'

In his critical discussion of 'Atomism', the communitarian political philosopher Charles Taylor describes atomism (or methodological individualism) as 'a vision of society as in some sense constituted by individuals' for the fulfilment of primarily individual ends, or as a class of political doctrines 'which try to defend in some sense the priority of the individual and his rights over society, or which present a purely instrumental view of society' (Taylor 1985, 187). From the atomist point of view, all goods are - at least 'in the last analysis' or 'in the last resort' individual (Taylor 1997a, 128-129). Taylor does not define here holism, but it is not difficult to see that holism, on the contrary, conceives of society as a whole and gives priority to the community over the individual. Furthermore, in the holist perspective, there exist certain 'irreducibly social goods' (Taylor 1997a, 134ff.)

1 Henceforth I will refer to the German version of this essay (Takács 2007).
In his later study entitled 'Cross-Purposes: The Liberal-Communitarian Debate', Taylor presents a slightly different definition of atomist ontology, and, what is more important, differentiates ontological questions related to the nature of society or social life from so-called 'advocacy issues' concerning moral and political standpoints. As regards the latter:

Here there is a gamut of positions, which at one end give primacy to individual rights and freedom and, at the other, give higher priority to community life or the good of collectivities. We could describe the positions on this scale as more or less individualist and collectivist. (Taylor 1997b, 181)

It is a significant difference, first, that in the case of atomism and holism, Taylor does not speak of degrees. Secondly, it seems clear to me that Taylor deviates here from his original discussion of atomism which does not strictly distinguish between ontological and political-moral questions. I think these two types of questions are much more interrelated than Taylor allows in this later writing. Therefore I will also draw, with some important reservations, on the conceptual framework provided by Fred D. Miller in his book on Aristotle's Politics (Miller 1995, ch. 6). According to Miller, even though individualistic and holistic conceptions of society have profoundly different implications, one should not speak simply of holism and individualism but of a wide spectrum of possible positions ranging from extreme individualism to extreme holism, including the intermediate standpoints of moderate individualism and moderate holism; and the most crucial debates are to be found in this 'central' area. To this we can add that in all the divergent positions of the scale ontological views seem to be interwoven with moral and political stances.

\section{The problem}

Theories of the common good are usually considered as reflecting a holist understanding of society, whereas doctrines of individual rights are generally regarded as manifestations of the atomist view. This produces an apparent tension between the two types of theories, which seems to be supported by the historical fact that while on the one hand Aristotle, Cicero, Aquinas and other classical theoreticians of the common good did not have a doctrine of individual rights, modern natural rights theorists on the other had a strong tendency to reduce the public good to the sum of individual goods or rights. Hobbes, for instance, clearly rejected any idea of summum bonum (highest good), ${ }^{2}$ and founded the state entirely on self-interest and

2 Hobbes categorically asserted (Leviathan ch. 11, 70): 'there is no such Finis ultimus, (utmost ayme,) nor Summum Bonum, (greatest Good,) as is spoken of in the Books of the Old Moral Philosophers.' 
fear. Locke, in his turn, equated the public good with 'the good of every particular Member of that Society' (Two Treatises of Government bk. 1, ch. 9, § 92, 210). This ostensible opposition is overstated and formulated in an uncompromising fashion by certain contemporary political philosophers representing the two respective traditions of thought, most particularly by Alasdair MacIntyre and Robert Nozick. While for MacIntyre natural or human rights simply do not exist, and 'belief in them is one with belief in witches and in unicorns' (MacIntyre 1981, 69), in Nozick's view 'there is no social entity with a good that undergoes some sacrifice for its own good. There are only individual people, different individual people, with their own individual lives. [...] Nothing more' (Nozick 1974, 32-33).

\subsection{Solution}

In seeking a common ground between the conception of public good and that of individual rights, it is common and it seems logical - at least at first sight - to start from two modern counterparts of the classical idea of common good, the Rousseauian concept of 'volonté générale' and the utilitarian notion of 'public interest', considering that these ideas take an individualist view of political society. But paradoxically, even though proceeding from the individual, both tend to supersede and neglect the individual's will, interest and rights (Takács 2007, 534-536).

For Rousseau, the chief aim of the social contract is to find a 'form of association which will defend and protect with the whole common force the person and goods of each associate, and in which each, while uniting himself with all, may still obey himself alone, and remain as free as before' (The Social Contract bk. 1 , ch. 6, 14). This markedly individualist approach notwithstanding, the 'general will', as understood by Rousseau, has become a common scarecrow against the idea of public good. This can be easily explained by the fact that it has virtually nothing to do with the actual will of either the individual or the people, still it 'is always right and tends to the public advantage' (ibid., bk. 2, ch. 3, 25); and, accordingly, 'whoever refuses to obey the general will shall be compelled to do so by the whole body. This means nothing less than that he will be forced to be free' (ibid., bk. 1, ch. 7, 18). Moreover, Rousseau emphatically insisted that each individual should be perfectly independent of other individuals, but at the same time totally dependent on the state, 'as the strength of the State can alone secure the liberty of its members' (ibid., bk. 2, ch. 12, 48).

Bentham, as is well known, identified the common interest with 'the greatest happiness of the greatest number.' He considered the axiom of utility maximization as 'the measure of right and wrong' (Bentham 1838b, Preface to the First Edition, 227), and described individual 'good' or 'happiness' as the predominance of pleasure over pain: 'Nature has placed mankind under the governance of two sovereign masters, pain and pleasure. It is for them alone to point out what we ought to do, as well as to determine what we shall do' (Bentham 1838a, ch. 1, 1). Bentham thought it possible to quantify happiness, and hence regarded 'public interest' as the simple aggregate of the interests of individuals, having no separate quality that would distinguish it from individual utility. ${ }^{3}$ This, however, is not the sole problem with Bentham's theory. The utilitarian calculus does not take into account differences between persons. Consequently, it is indifferent as to how public goods are distributed among the members of society, and can thus permit the sacrifice of the goods or the limitation of the fundamental rights of certain individuals for the sake of general welfare (Takács 2007, 535-536).

\subsection{Solution II}

So this way seems to lead to an impasse. Another possible solution is to try to bring the classical, ancient idea of the common good closer to atomist or nominalist ontology. This is the essential goal of Fred Miller's reinterpretation of The Politics. Miller maintains that Aristotle's discussion of the common good or common advantage is open to different readings:

One line of interpretation is individualistic: to promote the common advantage is to promote the end of its individual members. The polis is happy or flourishing provided that its individual citizens are happy. Hence, the best constitution must take seriously the fact that its members are distinct individuals and must respect the interests of each of them. Another line of interpretation is holistic: the polis resembles an organism in that it has an end which is distinct from, and superior to, the end of its individual members. (Miller 1995, 194)

Miller argues that the Aristotelian concept of common good rests not upon a holist but a 'moderate-individualistic' understanding of society, which does not differentiate between the political community's good and that of its members (Miller 1995, 204-205, 211-224). He claims, for instance, that Aristotle did not exactly say that the good of the city-state exceeds that of a single individual, but only that it is better to attain and preserve the good of the city-state (Miller 1995, 193).

However, this view does not seem convincing. First, this interpretation, as we will see later in detail, is far removed from Aristotle's original intentions and words. To take only one illustration, in Book One of The Politics (ch. 2, 1253a, 14) the Greek philosopher wrote: 'The proof that the state is a creation of nature and

3 See e.g. Bentham 1838c, pt. 1, ch. 15, 321: 'This public interest which you personify, is only an abstract term: it represents only the mass of the interests of individuals. 
prior to the individual is that the individual, when isolated, is not self-sufficing; and therefore he is like a part in relation to the whole.' Secondly, and more importantly, Miller's reading of Aristotle leads to the same problem of reductionism I have pointed out in the case of Hobbes, Locke and Bentham: in this perspective, the public good signifies no more than the sum of the goods of individuals and thereby inevitably loses its separate quality. Therefore, I think, it proves only that certain moderate forms of individualism are not incompatible with the notion of common good; e.g. one that holds that the individual's good and perfection includes other-regarding virtuous activities and hence requires participation in the political community (ibid., 200, 205).

\subsection{Solution III}

Consequently, taking everything into consideration, the only alternative that remains is to hark back to the original - ancient and medieval - Aristotelian conception of the common good. Above all, it should be stressed that the question whether to use the terms 'will' and 'interest' or the word 'good' is much more than a lis de verbis; it has real theoretical relevance. Although both Aristotle and Thomas Aquinas used the phrase 'common good' (koinon agathon/bonum commune) interchangeably with the expression 'common advantage' (koinon sympheron/utilitas communis), the primary concept of Aristotelian ethics is the 'good.' This is in sharp contrast to e.g. John Rawls's political philosophy which gives priority to the notion of right over that of the good (Rawls 1971, 31-32). Besides the fundamental significance of the fact that, in contrast to the diversity of connotations of the words 'will', 'interest', 'benefit', 'utility', etc., the notion of human 'good' self-evidently implies moral rightness, it also inherently involves some sort of dialectic between the good of the community and the individual's good, which seems to be an organic element of any theory of the common good.

At the beginning of the Nicomachean Ethics, Aristotle declared politics to be the 'highest master science' on the ground that

even if the good is the same for an individual as for a city, that of the city is obviously a greater and more complete thing to obtain and preserve. For while the good of an individual is a desirable thing, what is good for a people or for cities is a nobler and more godlike thing. (Nicomachean Ethics bk. 1, ch. 2, 1094b, 4)

This argument combines what might otherwise be seen as mutually exclusive alternatives: the statement that the common good is the same as the individual good, and the principle that the common good is superior to the individual good (Kempshall 1999, 26). In asserting that happiness is the same for a single human being and for the entire polis, Aristotle meant that it is the same in kind, that is, the same standard should be used in evaluating whether an individual human being or a community of human beings is happy: the life of virtue (Miller 1995, 213-214). On the other hand, Aristotle maintained that the common good of the city-state is not only quantitatively but also qualitatively different from the individual good of one person, inasmuch as 'the state is by nature clearly prior to the family and to the individual, since the whole is of necessity prior to the part' (The Politics bk. 1, ch. $2,1253 \mathrm{a}, 14){ }^{4}$

\section{Ontology of the common good}

If we approach Aristotle's above assertions and their implications from the perspective of ontology, we can arrive at the conclusion that it is probably more than a mere coincidence that the most influential theories of the common good have been developed on the philosophical basis of moderate realism. It is certain that a coherent doctrine of the common good must find a place on the spectrum of metaphysical views somewhere between extreme realism or holism and extreme nominalism or atomism. But where exactly? Let us have a closer look at it.

An extreme nominalist or atomist conception of society bases political and social cooperation exclusively on self-interest. Consequently, it acknowledges only 'convergent goods' (in Taylor's terminology), e.g. public safety, which are manifestations of collective instrumental action. These goods are merely convergent, because the fact that they are secured collectively does not in itself render them 'common' in the strict sense:

It has nothing to do with what makes them goods. Security as a valued end is always security for A, and for B, and for C. It is in no wise a different good, let alone a more valued one, because it is in fact ensured collectively. (Taylor 1997b, 191)

Contrary to this, the authentic notion of common good makes sense only if we accept the existence of 'irreducibly social goods', which are not 'decomposable into' or 'reducible to' individual goods. The examples given by Taylor are language, culture, positive liberty as 'participatory self-rule', 'frank and equal relations', and so on (Taylor 1997a, $134 \mathrm{ff}$ ).

Arguably, a meaningful concept of common good requires not only the rejection of extreme atomism but also the accentuation of civic or political friendship, which Aristotle called 'the greatest good of states' (The Politics bk. 2, ch. 4, 1262b, 34).

4 For a similar argument in Thomas Aquinas, see Summa theologiae IIaIIae 58, a. 7, ad 2. 
The Stagirite professed a thoroughly social view of human fulfilment. As MacIntyre points out, Aristotle thought that human beings can only achieve their proper end within the polis, and he believed that 'a community whose shared aim is the realization of the human good presupposes [...] a wide range of agreement in that community on goods and virtues' and necessitates a special bond between citizens (MacIntyre 1981, 146). As Aristotle himself put it:

Friendship seems also to hold cities together, and lawgivers to care more about it than about justice; for concord seems to be something like friendship, and this is what they aim at most of all, while taking special pains to eliminate civil conflict as something hostile.

(Nicomachean Ethics bk. 8, ch. 1, 1155a, 144)

This opinion seems evidently to imply, pace Miller (1995, 207-209), a moderate holist view of society.

On the other hand, a coherent concept of common good also excludes an extreme version of holism, as represented, for instance, by the idealism of Plato or Hegel, considering the state as the ultimate end of the individual, who exists for the sake of the whole. In reality, good citizens are supposed to like the community they belong to because the goal at which it aims - virtuous activity - is the ultimate good at which human beings should aim (Kraut 2002, 353). As it is well known, Aristotle overtly and vehemently opposed Plato's theory of the ideal state, especially the communistic tendencies inherent in it. In addition, he criticised the Platonist doctrine that there is only one single form of Good, thereby endorsing a certain degree of pluralism:

Unity there should be, both of the family and of the state, but in some respects only. For there is a point at which a state may attain such a degree of unity as to be no longer a state, or at which, without actually ceasing to exist, it will become an inferior state, like harmony passing into unison, or rhythm which has been reduced to a single foot. (The Politics bk. 2, ch. 5, 1263b, 37)

This way, the moderate holist conception of the common good avoids the strict subordination of the individual to the body politic, and regards the good of the community as including the good of its individual members. Furthermore, it is important to stress that according to the classical theory of the public good, state power only acts as a defensor pacis; it safeguards, but does not itself determine or create the common good. As Péter Takács pertinently observes: 'Nicht der Gesetzgeber sagt es, worin dieses Gut besteht, denn das ist auch für ihn gegeben. Die Staatsgewalt ist weder Besitzer, noch Festleger oder Garantie des Gemeinwohls, sondern sein Behüter und den Möglichkeiten gemäß sein Förderer' (Takács 2007, 537).
But what if John Rawls is right in affirming that in modern democracies the pluralism of values is irreducible (Rawls 1987,4) A tentative Aristotelian answer to this embarrassing question, proposed by Richard Kraut, might be that even if the members of a given society cannot achieve a consensus about what their good or well-being is, they can still manage to agree upon a conception of good citizenship as the common goal of the community:

The solution to this problem consists in rejecting its assumption that citizens can agree that their city is pursuing the common good only if they achieve a consensus about what well-being is. Suppose they have no such consensus, but nonetheless agree that their city ought to promote the conditions that encourage each citizen to be a certain kind of person, namely a good citizen. That, according to Aristotle, would be a way of promoting the common good, and not merely what seems good. (Kraut 2002, 398)

The citizens of such a political community, not sharing a common conception of the good life, can take the good pursued through collective decisions to be one thing, and the good pursued individually to be another, but so long as their allegiance to the outcome of collective decisions is strong enough, the state will be stable, and by fostering the virtue of the good citizen as an approximation of the virtue of the good man, it will realise considerable value. (ibid., 399)

\section{The common good and the individual good}

It is a standard thesis of the classical doctrine of the common good that in case of conflict the good of the community should take precedence over that of the individual (Takács 2007, 531-533). As Cicero famously formulated this principle: 'salus populi suprema lex esto' (De legibus bk. 3, ch. $3, \S 8,91$ ). Nevertheless, in the ancient and medieval Aristotelian way of thinking the common and the individual good were seen as typically existing in harmony with one another rather than in a state of conflict (Tierney 1997, 313). For, after all, these are but two different aspects or levels of the same good, and the boundary between the two is far from being impermeable. Accordingly, in this perspective the public good constitutes, on the one hand, the indispensable condition of the attainment of private good, and on the other hand, the good of the community presupposes that of the individual. As Takács underlines: 'das Gemeinwohl von den Gesichtspunkten des Individuums nicht getrennt werden kann [...] Ein Begriff des Gemeinwohls also, der dem Individualwohl gegenüber steht, ist unvorstellbar' (Takács 2007, 531). Political goodness ultimately depends upon what is good for the individual members of the state: it can attain happiness and the good life only because, and to the extent that, its citizens are happy and live well (Miller 1995, 197). 
In order to illustrate this point, I will quote here three relevant and revealing passages from three different representatives of the Aristotelian tradition. The first is Aristotle himself, followed by the statements of two scholastic Aristotelians, Thomas Aquinas and Francisco Suárez:

Everyone approves of and praises those who take special trouble to act nobly. And if everyone strives for what is noble and strains to do the noblest actions, everything will be as it should be for the common interest, and individually each will have the greatest goods, since such is virtue. So the good person should be a self-lover, since he will help himself as well as benefit others by doing noble acts (Nicomachean Ethics bk. 9, ch. 8, 1169a, 176).

Since therefore every man is a part of the State, it is impossible for any man to be good unless he is well adjusted to the common good; nor can the whole of anything be properly composed unless its parts are well adjusted to it. Hence it is impossible for the common good of the State to be secured unless the citizens are virtuous (Summa theologiae IaIIae 92, a. 1, ad 3,98 ).

For, in the first place, the good of private individuals [...] forms a part of the common good, when the former is not of a nature to exclude the latter good; being rather such that it is a necessary requisite in individuals $[\ldots]$ in order that the common good may result from this good enjoyed by private persons. (On Laws and God the Lawgiver bk. 1, ch. 7 , sect. 3, 91)

\section{Conclusion}

As it seems to me, the texts cited above clearly show the harmonious relationship and interdependence of common and private good in Aristotelian political and legal philosophy. In direct contrast to this approach, modern thought tends to postulate their disharmony and conflict. And for the most part, the dichotomy between the public and private good is transcended by reducing the common good to the aggregate of individual goods. This way, the public good unavoidably loses its independent quality. In the course of my argumentation, I have tried to reconstruct, albeit in a sketchy and tentative manner, the ontological presuppositions and conceptual premises that underlie the classical theory of the common good. If these theoretical preconditions can be fulfilled, as I believe (and hope to have demonstrated) they can, then both the Scylla of reducing and the Charybdis of opposing the common good to individual goods and rights can be avoided.

\section{Acknowledgements}

This study is published in the framework of the project no. TÁMOP-4.2.1.B-11/2/ KMR-2011-0002 at the Pázmány Péter Catholic University (the progress of scientific research at the PPCU).

\section{References}

Aquinas, Thomas. 1952-1956. Summa theologiae, edited by Pietro Caramello, 3 vols. Turin: Marietti.

Aquinas, Thomas. 2002. Summa theologiae IaIIae 92: The Effects of Law. In Political Writings, edited and translated by Robert W. Dyson, $95-100$. Cambridge: Cambridge University Press.

Aristotle. 1996. The Politics, translated by Benjamin Jowett. In The Politics and The Constitution of Athens, edited by Stephen Everson, 9-207. Cambridge: Cambridge University Press.

Aristotle. 2004. Nicomachean Ethics, edited and translated by Roger Crisp. Cambridge: Cambridge University Press.

Bentham, Jeremy. 1838a. An Introduction to the Principles of Morals and Legislation. In The Works of Jeremy Bentham, vol. 1, edited by John Bowring, 1-154. Edinburgh: Tait.

Bentham, Jeremy. 1838b. A Fragment on Government. In The Works of Jeremy Bentham, vol. 1, edited by John Bowring, 221-295. Edinburgh: Tait.

Bentham, Jeremy. 1838c. Principles of the Civil Code. In The Works of Jeremy Bentham, vol. 1, edited by John Bowring, 297-364. Edinburgh: Tait.

Cicero, Marcus Tullius. 1950. De legibus, edited by Konrad Ziegler. Heidelberg: Kerle.

Hobbes, Thomas. 1996. Leviathan, edited by Richard Tuck. Cambridge: Cambridge University Press.

Kempshall, Matthew S. 1999. The Common Good in Late Medieval Political Thought. Oxford: Clarendon Press.

Kraut, Richard. 2002. Aristotle: Political Philosophy. Oxford: Oxford University Press.

Locke, John. 1988. Two Treatises of Government, edited by Peter Laslett. Cambridge: Cambridge University Press.

MacIntyre, Alasdair. 1981. After Virtue: A Study in Moral Theory. Notre Dame (Ind.): University of Notre Dame Press.

Miller, Fred D. 1995. Nature, Justice, and Rights in Aristotle's Politics. Oxford: Clarendon Press. Nozick, Robert. 1974. Anarchy, State and Utopia. New York: Basic Books.

Rawls, John. 1971. A Theory of Justice. Cambridge (Mass.): Harvard University Press.

Rawls, John. 1987. The Idea of an Overlapping Consensus. Oxford Journal of Legal Studies 7: $1-25$.

Rousseau, Jean-Jacques. 1923. The Social Contract. In The Social Contract and Discourses, edited and translated by G.D.H. Cole, 1-123. London: Dent.

Suárez, Francisco. 1944. On Laws and God the Lawgiver (excerpts), translated by Gwladys L. Williams et al. In Selections from Three Works of Francisco Suárez, S.J., vol. 2, 1-646. Oxford: Clarendon Press.

Takács, Péter. 1998. A közjó [The Common Good]. In Iustum, aequum, salutare: Emlékkönyv Zlinszky János tiszteletére: Festschrift in Honour of Professor János Zlinszky, edited by Gábor Bánrévy, Gábor Jobbágyi and Csaba Varga, 269-276. Budapest: PPKE JÁK.

Takács, Péter. 2007. Der Begriff des Gemeinwohls. In Theatrum Legale Mundi: Symbola Cs. Varga Oblata, edited by Péter Cserne, István H. Szilágyi, Miklós Könczöl, Máté Paksy, Péter Takács and Szilárd Tattay, 527-537. Budapest: Szent István Társulat.

Taylor, Charles. 1985. Atomism. In Philosophy and the Human Sciences: Philosophical Papers 2, 187-210. Cambridge: Cambridge University Press. 
Taylor, Charles. 1997a. Irreducibly Social Goods. In Philosophical Arguments, 127-145. Cambridge (Mass.): Harvard University Press.

Taylor, Charles. 1997b. Cross-Purposes: The Liberal-Communitarian Debate. In Philosophical Arguments, 181-203. Cambridge (Mass.): Harvard University Press.

Tierney, Brian. 1997. The Idea of Natural Rights: Studies on Natural Rights, Natural Law and Church Law, 1150-1625. Atlanta, Scholars Press. 